\title{
PENGGUNAAN INTERNET DAN PELUANG BERWIRAUSAHA DI INDONESIA
}

\author{
Andi Alimuddin \\ Program Magister Ekonomi Kependudukan dan Ketenagakerjaan, Fakultas Ekonomi dan Bisnis \\ Universitas Indonesia, Gedung Dekanat FEB UI Kampus Widjojo Nitisastro, Jl. Prof. Dr. \\ Sumitro Djojohadikusumo, Kukusan, Beji, Depok, Jawa Barat 16424, Indonesia
}

Email: andi.alimuddin@ui.ac.id

\begin{abstract}
ABSTRAK
Saat ini, internet menjadi kebutuhan dalam kehidupan sosial dan ekonomi yang memberikan kemudahan dalam berkomunikasi dan interaksi sosial. Selain itu, kehadiran internet yang didukung oleh kemajuan teknologi digital diharapkan dapat memberikan peluang bisnis. Akses internet menjadi lebih mudah dengan semakin pesatnya penggunaan telepon seluler/handphone. Penelitian ini bertujuan untuk melihat pengaruh penggunaan internet terhadap peluang berwirausaha di Indonesia melalui metode analisis deskriptif dan regresi logistik biner. Riset ini menggunakan data Survei Sosial Ekonomi Nasional 2019. Wirausaha dalam riset ini dibatasi pada individu yang berusaha dibantu buruh tetap atau buruh dibayar pada rentang umur 25 sampai 44 tahun. Dari 348735 sampel yang menjadi unit analisis terdapat 7108 yang berwirausaha atau sekitar 2,04 persen. Penelitian ini menemukan bahwa individu yang menggunakan internet mempunyai peluang yang lebih tinggi untuk berwirausaha dibanding individu yang tidak menggunakan internet dan secara statistik temuan ini signifikan. Selain itu, tingkat pendidikan secara signifikan memengaruhi individu untuk berwirausaha, akan tetapi individu yang berpendidikan tinggi mempunyai kecenderungan yang lebih rendah untuk berwirausaha dibandingkan yang berpendidikan SMA ke bawah.
\end{abstract}

Kata Kunci: Internet, Regresi Logistik Biner, Wirausaha

\begin{abstract}
Currently, the internet is a necessity in social and economic life which provides convenience in communication and social interaction. In addition, the presence of the internet, which is supported by advances in digital technology, is expected to provide business opportunities. Internet access has become easier with the rapid use of cellular telephones. This study aims to examine the effect of internet use on entrepreneurial opportunities in Indonesia through descriptive analysis and binary logistic regression approaches. This research uses data from the 2019 National Socio-Economic Survey. Entrepreneurship in this research is limited to individuals who work assisted by
\end{abstract}


permanent workers or paid workers in the age range of 25 to 44 years. Of the 348735 samples that were the unit of analysis, 7108 were entrepreneurs, or about 2.04 percent. This study found that individuals who use the internet have a higher chance of becoming an entrepreneur than individuals who do not use the internet and this finding is statistically significant. In addition, the level of education significantly affects individuals to become entrepreneurs, but individuals with higher education have a lower tendency to become entrepreneurs than those with high school education and below.

Keywords: Binary Logistic Regression, Entrepreneurship, Internet

\section{PENDAHULUAN}

Era revolusi industri 4.0 ditandai dengan semakin meningkatnya teknologi komunikasi dan informasi. Saat ini, internet telah menjadi kebutuhan penting dalam kehidupan, terlebih lagi dengan semakin meningkatnya teknologi digital. Adanya internet dapat memudahkan komunikasi dan meningkatkan interaksi sosial (Castellacci \& ViñasBardolet, 2019). Berdasarkan hasil survei Asosiasi Penyelenggara Jasa Internet Indonesia (2018) diketahui bahwa penetrasi internet di Indonesia mencapai 64,8 persen dari total penduduk Indonesia tahun 2018. Angka ini meningkat 9,94 persen dibanding penetrasi internet tahun 2017. Sementara itu, menurut BPS (2018), pengguna internet mengalami peningkatan dari 17,14 persen tahun 2014 menjadi 39,90 persen tahun 2018.

Dalam lima tahun terakhir, penggunaan teknologi informasi dan komunikasi mengalami peningkatan yang pesat. Berdasarkan Indeks Pembangunan Teknologi Informasi dan Komunikasi (IP-TIK) tercatat bahwa IP-TIK tahun 2018 sebesar 5,07 (skala 0-10) meningkat 0,11 poin dari tahun 2017 (BPS, 2019a). Di sisi lain, individu yang menggunakan telepon seluler juga terus mengalami peningkatan dari tahun ke tahun.
Berdasarkan Statistik Telekomunikasi Indonesia 2018, tercatat 62,41 persen pengguna telepon seluler di Indonesia. Penggunaan internet mengunakan telepon seluler juga mengalami peningkatan dari 73,73 persen tahun 2014 menjadi 91,45 persen tahun 2018 (BPS, 2018).

Kemajuan teknologi informasi dan komunikasi dapat menciptakan kesempatan kerja khususnya pada pekerjaan yang dapat dilakukan dari jarak jauh atau yang dapat dikerjakan di rumah. Saat ini, rumah semakin dipandang sebagai tempat untuk kegiatan ekonomi yang menjanjikan, dan sebagian besar digunakan untuk wirausaha (Wynarczyk \& Graham, 2013). Menurut Dettling (2017) adanya akses internet di rumah memfasilitasi keseimbangan urusan pekerjaan dan keluarga.

Ketatnya persaingan dalam pasar kerja untuk mendapatkan pekerjaan yang diinginkan, menjadikan individu berusaha memanfaatkan peluang yang ada untuk memulai usaha sendiri. Menurut Barhatov et al., (2018), internet memunculkan inovasi yang mengubah cara orang berencana melakukan bisnis. Lebih lanjut dikatakan bahwa internet merupakan instrumen yang tepat untuk usaha kecil. Kewirausahaan membutuhkan 
banyak informasi tentang pasar, harga, kualitas, input, keterampilan, dan sebagainya (Moyi, 2019). Dengan kecanggihan internet maka berbagai informasi tersebut dapat mudah diperoleh.

Menurut beberapa literatur, individu yang bekerja sebagai wirausaha dibedakan dalam dua kategori, yaitu wirausaha opportunity dan necessity. Wirausaha opportunity mencerminkan individu yang memanfaatkan peluang bisnis dan mempunyai kemampuan untuk mengembangkan usahanya. Sementara itu, wirausaha necessity memilih berusaha karena tidak mempunyai pilihan yang lebih baik untuk bekerja (Reynolds et al., 2001).

Menurut Borjas (2016), ada trade off antara bekerja dan leisure. Individu yang memilih bekerja akan mengorbankan waktu luangnya (leisure). Dengan demikian, semakin banyak alokasi waktu untuk bekerja maka akan mengurangi waktu luang. Dengan memanfaatkan internet, seseorang dapat bekerja dari manapun.

Keuntungan lain yang diperoleh dengan memanfaatkan internet dalam berusaha yaitu dapat menurunkan biaya operasional. Usaha berbasis internet dapat menjangkau pasar dengan lebih mudah dan murah. Menurut Fairlie (2014), penggunaan komputer pribadi dalam berusaha terutama yang menggunakan internet dapat menurunkan biaya pemasaran, biaya investasi dan biaya operasional.

Era digital membawa perubahan dalam kewirausahaan. Perkembangan teknologi digital mengubah strategi bisnis tradisional. Kewirausahaan digital dipandang sebagai pilar penting untuk pertumbuhan ekonomi, penciptaan lapangan kerja, dan inovasi oleh banyak negara (Zhao \& Collier, 2017). Selain itu, hasil riset yang dilakukan oleh Cumming dan Johan (2010) di Kanada menemukan bahwa penggunaan internet meningkatkan

aktivitas kewirausahaan masyarakat perdesaan.

Penelitian yang dilakukan oleh Kotnik dan Stritar (2015) di Slovenia menyatakan bahwa penggunaan internet dan perangkat teknologi informasi dan komunikasi (TIK) terkait sangat memengaruhi transaksi ekonomi. Penggunaan TIK membuka peluang berwirausaha dan mengurangi keunggulan kompetitif perusahaan besar, sehingga memberi ruang bagi perusahaan kecil dan menengah. Lebih lanjut disampaikan bahwa e-commerce menciptakan peluang baru bagi usaha kecil, dengan membuat ketersediaan produk dan harga menjadi lebih transparan.

Hasil survei e-commerce 2019 menunjukkan bahwa terdapat 15,08 persen usaha e-commerce di Indonesia (BPS, 2019b). Lapangan usaha yang dominan melakukan usaha e-commerce yaitu pada kategori $G$ (perdagangan besar dan eceran, reparasi dan perawatan mobil dan sepeda motor) sebesar 44,31 persen. Kemudian terbanyak kedua pada kategori I (penyediaan akomodasi dan penyediaan makan dan minum) sebesar 18,11 persen. E-commerce sangat bergantung pada ketersediaan akses internet.

Kecenderungan untuk berwirausaha ditentukan oleh berbagai faktor. Dalam analisisnya, Qorraj (2017), menemukan bahwa 
tingkat pendidikan tidak berperan penting terhadap kinerja kewirausahaan dibandingkan dengan faktor lain seperti jenis kelamin dan status perkawinan. Berdasarkan riset yang dilakukan Cuberes et al., (2019), di 40 negara Eropa mengenai kesenjangan gender dalam berwirausaha menemukan bahwa kecenderungan laki-laki untuk berwirausaha lebih tinggi dibanding perempuan.

Penelitian yang dilakukan oleh Zhu et al., (2019), mengenai dampak penggunaan internet terhadap kewirausahaan pekerja migran di China menemukan bahwa penggunaan internet secara signifikan meningkatkan kecenderungan berwirausaha. Temuan ini didukung oleh fakta bahwa penggunaan internet menjadikan social network individu meningkat. Hal ini yang kemudian menjembatani peluang berwirausaha menjadi meningkat.

Riset yang dilakukan oleh Jinchuan dan Weiwei (2017), mengenai dampak penggunaan internet terhadap kewirausahaan di China menemukan bahwa penggunaan internet meningkatkan peluang individu untuk berwirausaha. Internet dapat membantu individu merespon dengan cepat perubahan pasar sehingga mengurangi risiko kewirausahaan. Hal ini menunjukkan bahwa keterbukaan dan kemudahan memperoleh informasi dapat membantu individu mengetahui kondisi pasar sehingga memudahkan kegiatan wirausaha.

Penggunaan internet diharapkan dapat memberikan dampak positif untuk perekonomian dengan terciptanya lapangan usaha yang memanfaatkan internet. Usaha yang berbasis digital dapat menurunkan biaya produksi karena memungkinkan membuka usaha tanpa toko secara fisik. Selain itu, memungkinkan untuk memasarkan produk barang/jasa dengan lebih luas dengan bantuan media sosial. Transaksi online pun bisa terjadi dengan adanya internet.

Oleh karena itu, riset ini bertujuan untuk melihat kontribusi penggunaan internet, telpon seluler dan karakteristik individu lainnya terhadap peluang berwirausaha. Wirausaha dalam tulisan ini dibatasi pada individu yang berusaha dibantu buruh tetap atau buruh dibayar. Penelitian ini menggunakan data Survei Sosial Ekonomi Nasional (Susenas) tahun 2019.

\section{METODE}

Riset ini menggunakan data cross section dari hasil Susenas yang dikumpulkan Badan Pusat Statistik (BPS) pada bulan Maret tahun 2019. Susenas merupakan survei skala nasional yang mengumpulkan berbagai keterangan demografi, sosial, dan ekonomi rumah tangga. Dalam penelitian ini, unit analisis difokuskan pada individu usia 25 - 44 tahun dan dari hasil filter data yang sesuai unit analisis maka diperoleh sampel sebanyak 348.735 responden. Menurut Borjas (2016), umur 25-44 tahun merupakan primary age untuk bekerja.

Berdasarkan kajian literatur, variabel bebas utama dalam riset ini adalah penggunaan internet. Adapun hipotesis penelitian yang dibangun adalah penggunaan internet berhubungan positif dan signifikan 
dengan peluang berwirausaha. Dengan kata lain, individu yang menggunakan internet mempunyai peluang yang lebih tinggi untuk berwirausaha (berusaha dibantu buruh tetap atau buruh dibayar).

Variabel outcome yang diuji dalam riset ini adalah status kewirausahaan. Variabel ini dibentuk menjadi variabel dikotomi yang bernilai 1 jika berwirausaha dan berkode 0 jika lainnya. Wirausaha dalam penelitian ini dibatasi hanya pada mereka yang berusaha dibantu buruh tetap atau buruh dibayar.

Variabel interest yang digunakan dalam penelitian ini adalah penggunaan internet (internet). Variabel ini merupakan variabel dummy, yang mana kode 1 jika menggunakan internet dan kode 0 jika tidak menggunakan internet. Adapun variabel kontrol yang diikutkan dalam analisis meliputi kepemilikan telepon seluler (ponsel), status perkawinan (marstat), tingkat pendidikan (educ), jenis kelamin (gender), umur (variabel kontinu), status tempat tinggal (area), dan status jawa/non jawa (pulau). Proses pengolahan data dalam riset seluruhnya menggunakan perangkat lunak olah data Stata 15.1.

Untuk memberikan gambaran umum karakteristik individu pada unit analisis maka digunakan analisis deskriptif berupa grafik dan tabulasi silang. Selain itu, untuk menganalisis hubungan antara penggunaan internet dan peluang berwirausaha (berusaha dibantu buruh tetap/buruh dibayar) maka digunakan model regresi logistik biner. Menurut Nachrowi dan Usman (2008), model logit dan probit dapat digunakan untuk menganalisis variabel terikat kategorik. Adapun model yang dibangun dengan metode regresi logistik biner: $\operatorname{Logit}(p)=\beta_{0}+\beta_{1}$ internet $+\beta_{2}$ ponsel $+\beta_{3}$ kawin $+\beta_{4}$ cerai $+\beta_{5}$ educ $+\beta_{6}$ gender $+\beta_{7}$ umur + $\beta_{8}$ area $+\beta_{9}$ pulau $+\varepsilon$.

\section{HASIL DAN PEMBAHASAN}

\section{Analisis Deskriptif}

Tabel 1 menunjukkan bahwa individu yang menggunakan internet lebih dari 50 persen. Sementara itu, responden yang memiliki handphone lebih banyak (77,44 persen) dibanding yang tidak memiliki handphone. Berdasarkan jenis kelamin, ada sebanyak 48,87 persen laki-laki dan 51,13 persen perempuan. Menurut tingkat pendidikan, terdapat 14 persen responden yang berpendidikan tinggi (Diploma I ke atas) dan 86 persen berpendidikan rendah (SMA ke bawah).

Tabel 1. Distribusi Sampel Menurut Karakteristik Yang Diamati

\begin{tabular}{llrr}
\hline \multicolumn{2}{c}{ Variabel dan Kategori } & Frek. & Persen \\
\hline \multirow{2}{*}{ Internet } & Ya & 179659 & 51,52 \\
& Tidak* & 169076 & 48,48 \\
Ponsel & Ya & 270061 & 77,44 \\
& Tidak* & 78674 & 22,56 \\
Gender & Laki-laki & 170432 & 48,87 \\
& Perempuan* & 178303 & 51,13 \\
\multirow{2}{*}{ Educ } & Tinggi & 48825 & 14,00 \\
& Rendah* & 299910 & 86,00 \\
Area & Urban & 143664 & 41,20 \\
& Rural* & 205071 & 58,80 \\
\multirow{3}{*}{ Marstat } & Kawin & 289435 & 82,99 \\
& Cerai & 14041 & 4,03 \\
\multirow{3}{*}{ Pulau } & Single* & 45259 & 12,98 \\
& Jawa & 97182 & 27,87 \\
Umur & Non Jawa* & 251553 & 72,13 \\
& 25-34 tahun & 165842 & 47,56 \\
& 35-44 tahun & 182893 & 52,44 \\
\hline
\end{tabular}

*kategori acuan dalam pemodelan regresi

Jika dilihat dari sebaran responden menurut status tempat tinggal, sebagian besar berada $\mathrm{dx}{ }^{`} \mathrm{i}$ 
perdesaan ( 58,8 persen) dan sebagian besar berstatus kawin (82,99 persen). Individu yang berumur 35-44 tahun lebih banyak dibanding yang berumur 25-34 tahun. Sementara itu, berdasarkan Gambar 1, terdapat 2,04 persen atau 7108 dari 348.735 individu berusia 25-44 tahun yang berusaha dibantu buruh tetap atau buruh dibayar yang mana dalam penelitian ini disebut berwirausaha.

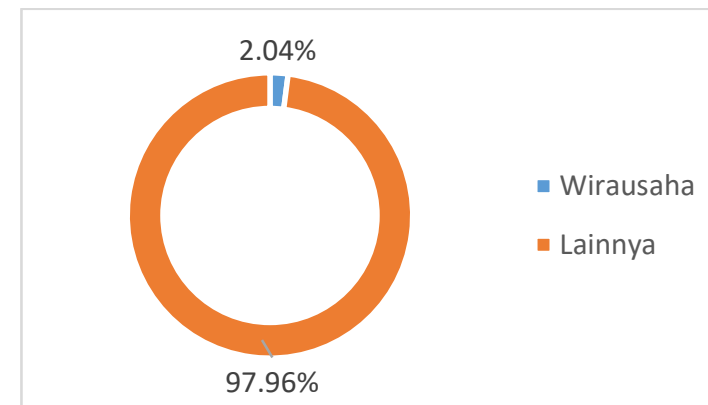

Gambar 1. Persentase Individu Usia

25-44 Tahun Menurut Status Berwirausaha

Mengacu pada Tabel 2, dapat
dikatakan bahwa terdapat kesenjangan antara individu usia 2544 tahun yang menggunakan internet dengan yang tidak menggunakan internet dalam berwirausaha. Hal ini terlihat dari persentase individu yang berwirausaha menggunakan internet lebih tinggi dibandingkan yang berwirausaha tanpa menggunakan internet, masing-masing sebesar 2,57 persen dan 1,48 persen. Begitupula mereka yang memiliki dan menggunakan telepon seluler lebih dominan untuk beriwirausaha dibanding yang tidak memiliki telepon seluler atau handphone.

Individu berusia 25-44 tahun yang berwirausaha kebanyakan lakilaki dibanding perempuan dengan perbandingan 3,33 persen dan 0,81 persen. Begitupula individu usia 25-44 tahun yang tinggal di perkotaan lebih besar persentasenya yang berwirausaha dibanding yang tinggal di perdesaan. Jika diliat dari status perkawinan, mereka yang pernah kawin (kawin dan cerai) mempunyai persentase yang lebih tinggi dibandingkan mereka yang masih single untuk berwirausaha. Hal ini dimungkinkan bahwa adanya urusan rumah tangga menjadi pertimbangan untuk lebih memilih menjadi wirausaha dan kehadiran internet memberikan peluang untuk dapat menjalankan usaha, misalnya dari rumah.

Tabel 2. Karakteristik Sampel Menurut Status Wirausaha

\begin{tabular}{|c|c|c|c|}
\hline \multirow{2}{*}{\multicolumn{2}{|c|}{$\begin{array}{l}\text { Variabel dan } \\
\text { Kategori }\end{array}$}} & \multicolumn{2}{|c|}{$\begin{array}{c}\text { Status Wirausaha } \\
(\%)\end{array}$} \\
\hline & & $\mathrm{Ya}$ & Lainnya \\
\hline \multirow{2}{*}{ internet } & $\mathrm{Ya}$ & 2,57 & 97,43 \\
\hline & Tidak & 1,48 & 98,52 \\
\hline \multirow{2}{*}{ ponsel } & Ya & 2,39 & 97,61 \\
\hline & Tidak & 0,82 & 99,18 \\
\hline \multirow{2}{*}{ gender } & Laki-laki & 3,33 & 96,67 \\
\hline & Perempuan & 0,81 & 99,19 \\
\hline \multirow{2}{*}{ educ } & Tinggi & 1,90 & 98,10 \\
\hline & Rendah & 2,06 & 97,94 \\
\hline \multirow{3}{*}{ area } & Urban & 2,30 & 97,70 \\
\hline & Rural & 1,86 & 98,14 \\
\hline & Kawin & 2,18 & 97,82 \\
\hline \multirow[t]{2}{*}{ marstat } & Cerai & 2,12 & 97,88 \\
\hline & single & 1,13 & 98,87 \\
\hline \multirow{2}{*}{ pulau } & Jawa & 2,16 & 97,84 \\
\hline & Non Jawa & 1,99 & 98,01 \\
\hline \multirow{2}{*}{ umur } & 25-34 tahun & 1,46 & 98,54 \\
\hline & 35-44 tahun & 2,56 & 97,44 \\
\hline
\end{tabular}

\section{Analisis Inferensial}

Sebelum dilakukan analisis inferensial dengan metode regresi logistik biner, terlebih dahulu dilakukan uji multikolinearitas dari masing-masing variabel independen. Metode Variance Inflation Factor (VIF) 
digunakan untuk mengecek adanya multikolinearitas. Nilai VIF menunjukkan tak satu pun variabel independen yang memiliki nilai VIF di atas 10 dan rata-rata nilai VIF yang dihasilkan sebesar 1,23 sehingga dapat dikatakan bahwa variabel yang digunakan terbebas dari multikolinearitas.

Tabel 3. Nilai VIF

\begin{tabular}{lcc}
\hline \multicolumn{1}{c}{ Variabel } & VIF & 1/VIF \\
\hline internet & 1,64 & 0.608876 \\
ponsel & 1,38 & 0.724001 \\
area & 1,18 & 0.850744 \\
educ & 1,16 & 0.863936 \\
umur & 1,16 & 0.864016 \\
marstat & 1,14 & 0.876187 \\
gender & 1,08 & 0.926942 \\
pulau & 1,10 & 0.909862 \\
\hline
\end{tabular}

Sesuai dengan hipotesis awal bahwa individu berusia 25 sampai 44 tahun yang menggunakan internet lebih cenderung untuk menjadi wirausaha dibandingkan individu yang tidak menggunakan internet. Hasil regresi logistik biner menunjukkan bahwa peluang menjadi wirausaha bagi mereka yang menggunakan internet 1,687 kali lebih tinggi dibandingkan mereka yang tidak menggunakan internet setelah dikontrol variabel lainnya. Angka ini signifikan secara statistik dan sejalan dengan hasil riset yang dilakukan oleh Zhu et al., (2019), di China yang menemukan bahwa penggunaan internet dapat meningkatkan peluang untuk berwirausaha sebesar 2 persen.

Temuan ini menunjukkan bahwa penggunaan internet dapat meningkatkan pengetahuan dan hubungan sosial seseorang. Dengan demikian, informasi yang diperoleh dengan mengakses internet dan dengan memanfaatkan jalinan pertemanan di media sosial, seseorang dapat mencari pengetahuan mengenai usaha yang akan dijalankan, misalnya bahan, cara pengolahan dan cara memasarkan. Seseorang akan tertarik berwirausaha jika mendapat pengetahuan mengenai bisnis.

Individu yang menggunakan telepon seluler atau handphone mempunyai kecenderungan menjadi wirausaha dengan odds ratio 1,855 kali lebih tinggi dibanding yang tidak memiliki dan menggunakan telepon seluler (dengan asumsi cateris paribus). Saat ini telepon seluler/handphone dianggap sebagai barang wajib bagi kebanyakan orang. Fungsi handphone tidak hanya untuk berkomunikasi tetapi juga dapat menjadi personal assistant yang dapat membantu dalam melakukan aktivitas.

\begin{tabular}{lcc}
\multicolumn{2}{c}{ Tabel 4. Hasil Regresi Logistik Biner } \\
\hline \multicolumn{1}{c}{ Variabel } & $\begin{array}{c}\text { Koefisien } \\
(\beta)\end{array}$ & $\begin{array}{c}\text { Odds } \\
\text { Ratio }\end{array}$ \\
\hline internet & $0,523^{* * *}$ & 1,687 \\
ponsel & $0,618^{* * *}$ & 1,855 \\
kawin & $0,771^{* * *}$ & 2,162 \\
cerai & $0,859^{* * *}$ & 2,361 \\
educ & $-0,202^{* * *}$ & 0,826 \\
gender & $1,388^{* * *}$ & 4,007 \\
umur & $0,055^{* * *}$ & 1,057 \\
area & $0,0553^{*}$ & 1.056 \\
pulau & $-0,084^{* *}$ & 0,919 \\
\hline
\end{tabular}

${ }^{*} \mathrm{p}<0,05,{ }^{* *} \mathrm{p}<0,01,{ }^{* * *} \mathrm{p}<0,001$

Tabel 4 menunjukkan bahwa setelah dikontrol variabel lainnya, individu yang berstatus kawin mempunyai kecenderungan untuk berwirausaha 2,162 kali lebih tinggi dibanding yang belum kawin. Begitupula mereka yang berstatus 
cerai mempunyai peluang untuk berwirausaha lebih tinggi 2,361 kali dibandingkan mereka yang belum kawin atau single. Hal ini diduga mereka yang berstatus kawin mempunyai tanggungan keluarga sehingga memilih menjadi wirausaha dan dengan adanya internet dapat mengelola usaha sambil mengurus rumah tangga.

Hasil regresi logistik biner menunjukkan bahwa peluang berwirausaha pada individu yang berpendidikan tinggi (minimal tamatan Diploma I) 0,826 kali lebih rendah dibandingkan mereka yang tamatan SMA ke bawah. Temuan ini sejalan dengan penelitian Zhu et al., (2019), mengenai dampak penggunaan internet terhadap peluang migran berwirausaha di China, yang mana mereka yang menamatkan pendidikan pada tingkat universitas mempunyai peluang yang lebih rendah untuk berwirausaha. Hal ini diduga mereka yang berpendidikan tinggi lebih cenderung untuk bekerja sebagai pegawai negeri, pegawai BUMN atau yang sejenis.

Kecenderungan individu berusia 25-44 tahun untuk berwirausaha di daerah perkotaan masih lebih tinggi dibandingkan perdesaan setelah dikontrol dengan variabel lainnya. Hal ini mungkin dipengaruhi oleh perbedaan keberadaan infrastruktur Teknologi Informasi dan Komunikasi di perkotaan dan perdesaan. Selain itu, pekerjaan di perdesaan masih didominasi oleh sektor pertanian.

Berdasarkan status pulau, mereka yang tinggal di luar pulau Jawa mempunyai kecenderungan yang lebih tinggi untuk menjadi wirausaha dibanding yang tinggal di pulau Jawa. Hal ini terlihat dari nilai odds ratio sebesar 0,919. Penjelasan yang mungkin bahwa mereka yang tinggal di pulau Jawa memiliki kesempatan yang besar bekerja sebagai buruh atau karyawan karena banyaknya pabrik atau industri di daerah Jawa.

\section{KESIMPULAN}

Penggunaan internet dapat memberikan dampak positif terhadap kewirausahaan di Indonesia. Dengan menggunakan regresi logistik biner ditemukan hasil bahwa individu yang menggunakan internet mempunyai peluang berwirausaha yang lebih tinggi dibandingkan individu yang tidak menggunakan internet. Keberadaan internet dapat memberikan kesempatan berusaha bagi siapapun.

Begitupula individu yang memiliki dan menggunakan telepon seluler mempunyai peluang berwirausaha yang lebih tinggi dibanding yang tidak menggunakan telepon seluler. Hal ini menunjukkan bahwa telepon seluler tidak hanya berfungsi sebagai alat komunikasi tetapi juga dapat menjadi alat untuk berwirausaha. Kegiatan promosi dan penjualan barang/jasa dapat dilakukan melalui telepon seluler dengan bantuan internet sehingga dapat menjangkau lebih luas calon konsumen.

Hal menarik lainnya yang ditemukan bahwa dengan asumsi cateris paribus, individu dengan tingkat pendidikan yang tinggi mempunyai peluang yang lebih rendah untuk berwirausaha dibandingkan mereka yang tamatan SMA ke bawah. Hal ini 
diduga mereka yang berpendidikan tinggi lebih cenderung bekerja sebagai pegawai negeri sipil atau pegawai BUMN atau sejenisnya. Individu yang berpendidikan tinggi diduga memiliki bargaining power yang lebih tinggi untuk bisa diterima di perusahaan.

\section{DAFTAR PUSTAKA}

Asosiasi Penyelenggara Jasa Internet Indonesia. (2018). Penetrasi \& Profil Perilaku Pengguna Internet Indonesia. Apjii, 51. https://apjii.or.id/survei2018s/d ownload/TK5oJYBSyd8iqHA2eC h4FsGELm3ubj

Barhatov, V., Campa, A., \& Pletnev, D. (2018). The Impact of InternetTechnologies Development on Small Business Success in Russia. Procedia - Social and Behavioral Sciences, 238, 552-561. https:// doi.org/10.1016/j.sbspro .2018.04.035

Borjas, G. J. (2016). Labor Economics. New York: Mc Graw Hill Education.

BPS. (2018). Statistik Telekomunikasi Indonesia 2018. Jakarta: Badan Pusat Statistik.

BPS. (2019a). Indeks Pembangunan Teknologi, Informasi, dan Komunikasi (ICT Development Index) 2018. In Subdirektorat Statistik Komunikasi dan Teknologi Informasi.

BPS. (2019b). Statistik E-Commerce 2019. In Badan Pusat Statistik. https://www.bps.go.id/publicat ion/2019/12/18/fd1e96b05342e4 79a83917c6/ statistik-ecommerce-2019.html
Castellacci, F., \& Viñas-Bardolet, C. (2019). Internet use and job satisfaction. Computers in Human Behavior, 90(September 2018), 141152.

https://doi.org/10.1016/j.chb.20 18.09.001

Cuberes, D., Priyanka, S., \& Teignier, M. (2019). The determinants of entrepreneurship gender gaps: A cross-country analysis. Review of Development Economics, 23(1), 72101.

https://doi.org/10.1111/rode.12 537

Cumming, D., \& Johan, S. (2010). The Differential impact of the internet on spurring regional entrepreneurship.

Entrepreneurship: Theory and Practice, 34(5), 857-883. https://doi.org/10.1111/j.15406520.2009.00348.x

Dettling, L. J. (2017). Broadband in the labor market: The impact of residential high-speed internet on married women's labor force participation. Industrial and Labor Relations Review, 70(2), 451-482. https://doi.org/10.1177/0019793 916644721

Fairlie, R. W. (2014). The Personal Computer and Entrepreneurship.

Jinchuan, S., \& Weiwei, W. (2017). The Impact of Internet Use on Entrepreneurship:An Empirical Analysis Based on the Micro-level Data. Journal of Zhejiang University, 3(4), 159-175. https://doi.org/10.3785/j.issn.10 08-942X.CN336000/C.2016.09.083 
Kotnik, P., \& Stritar, R. (2015). ICT as the Facilitator of Entrepreneurial Activity: An Empirical Investigation. Amfiteatru Economic, 17(38), 277-290.

Moyi, E. D. (2019). The effect of mobile technology on self-employment in Kenya. Journal of Global Entrepreneurship Research, 9(1), 113. https:/ / doi.org/10.1186/s40497019-0180-4

Nachrowi, N. D., \& Usman, H. (2008). Penggunaan Teknik Ekonometri (Edisi Revisi). PT RajaGrafindo Persada.

Qorraj, G. (2017). Does Education Matter for Entrepreneurship Activities? The Case of Kosovo. International Journal of Management, Knowledge and Learning, 6(1), 131-144.

Reynolds, P. D., Autio, E., \& Camp, M. (2001). Global Entrepreneurship Monitor: 2001 Executive Report. Regional Studies.

Wynarczyk, P., \& Graham, J. (2013). The impact of connectivity technology on home-based business venturing: The case of women in the North East of England. Local Economy, 28(5), 451-470.

https:// doi.org/10.1177/0269094 213491700

Zhao, F., \& Collier, A. (2017). Digital Entrepreneurship: Research and Practice (PDF Download Available). 9th Annual Conference of the EuroMed Academy of Business, September, 2173-2182. https://www.researchgate.net/p
ublication/309242001_Digital_En trepreneurship_Research_and_Pr actice

Zhu, Z., Leng, C., Chen, Q., \& Delgado, M. S. (2019). The Impact of Internet Use on Entrepreneurship of Migrant Workers in China. 2019 Annual Meeting, July 21-23, Atlanta, Georgia 290988, Agricultural and Applied Economics Association. 